\title{
The Essential of the 1945 Constitution and the Agreement of the Amendment of the 1945 Constitution: A Comparison of the Constitutional Amendment ${ }^{1}$
}

\author{
Aidul Fitriciada Azhari \\ Fakultas Hukum Universitas Muhammadiyah Surakarta \\ Jl. Ahmad Yani Pabelan Surakarta \\ af_ciada@yahoo.com
}

\begin{abstract}
This research discusses two issues which are: First, (1) comparison of similarities and differences of the essence of Constitution and the amendment agreement of Constitution; Second, (2) consequence of those differences towards the current development of Constitution. Normative legal research and post-colonial theory methods are used to analyze the issues. Data are collected from legal materials through literary study and documentary study. With those methods, this research found that the difference between 1950 and 1999 agreement shows inconsistency and divergence in viewing Constitution. Besides that, the agreement on essence of Constitution is performed based on decolonialization paradigm, while the consent of People's Consultative Assembly in 1999 was mostly based on democractization paradigm.
\end{abstract}

Key words : Constitution, amendment, democratization

\begin{abstract}
Abstrak
Penelitian ini mengkaji dua permasalahan yakni: Pertama, (1) perbandingan persamaan dan perbedaan esensial antara Undang-Undang dasar 1945 dan kesepakatan amandemen Undang-undang Dasar 1945; Kedua, (2) konsekuensi dari perbedaan tersebut terhadap perkembangan Undang-Undang Dasar 1945 sekarang. Untuk mengkaji permasalahan di atas, digunakan metode penelitian hukum normatif serta teori poskolonial. Data dikumpulkan dari bahan hukum dengan menggunakan studi kepustakaan dan studi dokumenter. Dengan metode penelitian yang demikian, penelitian ini menemukan bahwa perbedaan antara kesepakatan 1950 dan 1999 memperlihatkan adanya inkonsistensi sekaligus pergeseran paradigma dalam memandang Undang-Undang Dasar 1945. Selain itu, kesepakatan tentang esensi Undang-Undang Dasar 1945 dilakukan berdasarkan paradigma dekolonisasi, sedangkan kesepakatan Majelis Permusyawaratan Rakyat pada 1999 lebih didasari oleh paradigma demokratisasi.
\end{abstract}

Kata kunci: Amandemen UUD 1945, amandemen, demokratisasi

\footnotetext{
1 This article is written based on the research titled "The 1945 Constitution as a Revolutiegrondwet", which was funded by Competency Grant from The Directorate of Higher Education (DIKTI) Ministry of National Education of the Republic of Indonesia, in 2009 and 2010. Thanks to Dr. Saefuddin, Drs. Revrisond Basywir, MA and participants at a faculty colloquium at the Faculty of Law Muhammadiyah University of Surakarta for their comments on a previous draft.
} 


\section{Statement of Problems}

The "essentialia UUD 1945" or the essential of the 1945 Constitution - hereafter called as "the essential" - is a term that used when the Republic of Indonesia adopted the Provisional Constitution of 1950. ${ }^{2}$ This term reffers to an agreement between the Indonesian political leaders when they should arranged a new constitution after they accepted the Round Table Conference agreements and then refused the Republic of the United State of Indonesia (RUSI) in 1950. Substantially, the essential of the 1945 Constitution reffers to three articles namely the article 27, 29, and 33 of the 1945 Constitution. The Indonesian political leaders viewed those articles as the fundamental of the 1945 Constitution, consequently they may not change those articles even when the 1945 Constitution has been altered or amended. In history, the Provisional Constitution of 1950 adopted those articles without any change at all, textually as well as substantially.

In the other side, the People Consultative Assembly (MPR) has amended the 1945 Constitution four times, between 1999 and 2002. Definitely, the amendment did not mean that the MPR could change entire of the 1945 Constitution. At this point, there were some agreements among the members of the MPR on the some subjects that the MPRS cannot change. Those agreements contained of the Preamble of the 1945 Constitution, the system of government, the form of unitary states, the annotations of the 1945 Constitution, and the method of amendment. ${ }^{3}$

The agreement among the members of the MPR - hereafter called as "the agreement" - showed a similar situation with the essential of the 1945 Constitution in relation with an agreement on the some subjects that the constitution drafter cannot change when they will alter the 1945 Constitution. However, the subjects of those agreements are different. The essential consisted of three articles of the 1945 Constitution, while the agreements among the MPR members comprise five subjects in different issues. Moreover, in the paradigm, the essential of the 1945 Constitution has purpose to conduct decolonization, while the agreement of the MPR is motivated to carry out democratization.

\footnotetext{
${ }^{2}$ Muhammad Yamin, Naskah Persiapan Undang-Undang Dasar 1945, 1960, pp. 41-42. George McTurnan Kahin, Nationalism and Revolution in Indonesia, Cornell University Press, Ithaca/London, 1952, p. 401.

${ }^{3}$ Badan Pekerja MPR, Perubahan Pertama dan Perubahan Kedua UUD 1945: Baban Penjelasan BP-MPR dalam Rangka Memasyarakatkan Hasil Sidang Umum MPR 1999 dan Sidang Tabunan MPR 1999, Sekretariat MPR: 2000, pp. 10-13.
} 


\section{Problems Statement}

From the background above, this research was conducted: first to compare similarities and differences between the essential of the 1945 Constitution and the agreement of the amendment of the 1945 Constitution; and second the consequences of those comparisons over the development of the 1945 Constitution nowadays. In the other meaning, this research will evaluate the amendment of the 1945 Constitution based on the essential of the 1945 Constitution in its comparison with the agreement of the MPR members on the amendment of the 1945 Constitution.

\section{Aim of Research}

According to the problem statement, the purpose of this research is to know the comparison between the essential of the 1945 Constitution and the agreement on the amendment of the 1945 Constitution and its consequences on the development of the 1945 Constitution nowadays.

\section{Research Procedure}

This research used the normative approach and strengthened by social and political analysis. The data was collected from the legal material such as the Indonesian constitution, legal document, legal journal, books, internet, and the other sources.

\section{Theoritical Framwork}

This research uses postcolonial theory to explain the 1945 Constitution as a text that comprises ideas in relation with colonialism and its fight against colonialism. Postcolonial is distinguished with the formal decolonization in the sense liberation formally from colonial domination. The formal decolonization does not erase colonial system automatically. Even a nation can get formal decolonization, yet at the same time life under neo-colonialism in the sense that nation still dependence in economy and/or cultural. ${ }^{4}$ The realities in the recent global situation show that the formal decolonization or the unbalance relations in the colonial system have been

\footnotetext{
${ }^{4}$ Ani Loomba, Kolonialisme/Pascakolonialisme, Bentang Budaya, Yogyakarta, 2003, p. 9
} 
developed toward the new unbalance relations between "the first world" and "the third world". The new world order has created forms of new dependency in economy, politics, and cultural of several states against another states.

Therefore, postcolonial more than mere formal decolonization but detach from colonial domination and legacy. ${ }^{5}$ It means postcolonial not only discourses after formal decolonization but include various discourses before formal decolonization. In Indonesian context, for instance, the Sumpah Pemuda event on 28 October 1928 was a postcolonial discourse although happened before formal decolonization on 17 August 1945.

Theoretically, there are two model of the postcolonial discourse, which are the national and the hybrid models. The national model emphasizes on relation between colony country and ex-colonialist. The main concept of national model is dominationsubordination relations. A paradigmatic case of this model is the United States of America. Although the USA is an ex-colony of the British, but the USA had effort to create a national discourse, which differred from the British. On his constitution, the founding fathers of the USA did not follow the British model, but they developed a different model, even a counter model, against the British constitution. Therefore, the USA appears as a new country, which differs from his imperial.

The hybrid model focuses on a compound of colony and ex-colonialist in order to create a new discourse. The main concept of hybrid model is diaspora-creolization. The concept of diaspora-creolization is concerned with the migration of black people from Africa to Europe and America that then creates the crossing of culture with the imperial and the creols - that is the European descendants who birth in colony region. The crossing of culture creates a new and a complex identity, which differs with the imperial country. In contrast with the national model, the hybrid model more emphasizes more on ethnicity than nationality. The hybrid model appears particularly in the Latin America. ${ }^{6}$

Based on above explanation, the proper postcolonial model with Indonesia is the national model. Similar with the USA, the postcolonial discourse of Indonesia has characteristic as a counter against domination and legacy of the Netherlands colonialism through the creation of a national identity, which differs from ex-imperial

\footnotetext{
${ }^{5}$ Ibid., p. 15.

${ }^{6}$ Ibid., pp. 223-237. Benedict Anderson, Komunitas-Komunitas Imajiner: Renungan tentang Asal-Usul dan Penyebaran Nasionalisme, Yogyakarta: Pustaka Pelajar/Insist, 1999, pp. 67-93.
} 
country. Even Indonesia was a step more than the USA with the creation of a national language, that is bahasa Indonesia, and leave the Dutch language as the national language.

\section{Discussion}

\section{Essential and the Continuity of the 1945 Constitution}

After independence war during 1945-1949, Indonesia obtained the sovereignty from the Netherlands through the agreement of the Round Table Conference on 27 December 1949. Based on the agreement, the Republic of Indonesia (RI) was changed from unitary state to federal state - called as The Republic of the United States of Indonesia (RUSI). This federal state was founded based on the RUSI Constitution, except in region of the RI, which exercised the 1945 Constitution according to autonomy principle to create the state law. ${ }^{7}$ Thus, the 1945 Constitution was applied in the RUSI, although in the restricted region.

However, the RUSI existed only eight months because Indonesian people in every region rejected federal state and wished to return to a unitary state. Accordingly, Mohammad Natsir proposed a motion in the parliament, which recommended for Indonesia to reapply the unitary state. ${ }^{8}$ The parliament accepted the motion, well known as the Mosi Integral or Mosi Natsir, and eventually on 17 August 1950 Indonesia reapplied the unitary state. At the same time, Indonesia adopted the Provisional Constitution of 1950 as substitute of the RUSI Constitution.

Formally, the Provisional Constitution of 1950 was a part of the agreement between the RI and the RUSI, which consisted of the amendment of the RUSI Constitution become the Provisional Constitution. The parliament ratified the amendment on 15 August 1950, so that the amendment famous as the Provisional Constitution of 1950.

In relation to the amendment of constitution, there is an agreement on the Provisional Constitution of 1950, that is "The Provisional Constitution of 1950 is acquired by the amendment of the RUSI Constitution, which contained the essential of the 1945 Constitution and added by the other parts of the RUSI Constitution. The essential of the 1945 Constitution consist of Article 27, article 29, and article 33 of the

${ }^{7}$ Articles 47 and 48 the RUSI Constitution.

8 “Mosi Integral Natsir", http://id.wikipedia.org/wiki/Mosi_Integral_Natsir (accessed on 20 July 2010) 
1945 Constitution." ${ }^{9}$ This agreement is very important because show the continuity of the 1945 Constitution and, in the other sense, the continuity of the Republic of Unitary-State of Indonesia, which proclaimed on 17 August 1945. ${ }^{10}$

In complete, those provisions of the essential are:

Article 27 :

(1) All citizens have equal status before the law and in government and shall abide by the law and the government without any exception.

(2) Every citizen has the right to work and to live in human dignity.

\section{Article 29:}

(1) The State shall be based upon the belief in the One and Only God.

(2) The State guarantees all persons the freedom of worship, each according to his/ her own religion or belief.

Article 33 :

(1) The economy shall be organized as a common endeavour based upon the principles of the family system.

(2) Sectors of production which are important for the country and affect the life of the people shall be controlled by the state.

(3) The land, the waters and the natural riches contained therein shall be controlled by the State and exploited to the greatest benefit of the people.

The adoption of those articles shows that basic ideas and principles of the 1945 Constitution has never lost in the Indonesian constitutional living, which has existed since 17 August 1945. Those articles are very fundamental for Indonesia because those have changed the legacy of Dutch colonial legal system. Briefly, those articles have sense of: a. the principle of equality or non-discrimination. This principle is very fundamental because it is contrary with colonial system, which was composed by racial discrimination, particularly discrimination of legal status between European, foreign East (Chinese and Arab), and indigene people. Based on non-discrimination principle, every kind of discrimination can be eradicated and all Indonesian citizens have equal status before law and government without exceptions; $b$. the right to work and to live in human dignity are kind of criticism against the practice of capitalism by the Netherlands-Indie, which exploited Indonesian people without respect to human dignity; c. the principle of monotheism obviously rejects secularism, which was

\footnotetext{
${ }^{9}$ Muhammad Yamin, Loc. Cit., George McTurnan Kahin, Loc. Cit.

${ }^{10}$ See Consideration Law No. 7 / 1950 on The Amendment of the Provisional Constitutution of RUSI become the Provisional Constitution of the RI (LNRI tahun 1950, Nr 56; TLN Nr 37, Tahun 1950).
} 
practiced by the Netherlands-Indie colonial system. Based on secularism, the Netherlands-Indie had oppressed Indonesian Muslims. Accordingly, the principle of monotheism shows that Indonesia as a national-state shall protect the freedom of religion and worship; $d$. the principle of economic is based on family-system or solidarity. This principle desires the colonial economic system based on capitalistic principle shall be transformed to the national economic system based on familial system (kekeluargaan). The family system is a kind of solidarity in economic system, which differs with the individualism as a core principle in capitalism.

Based on those articles, the essentially the 1945 Constitution desires a change or transformation radically from a colonial system, which discriminative, secular, and capitalistic, to a national system, which democratic, theistic, and collectivistic. At this point, the 1945 Constitution has role as a legal instrument for decolonization in Indonesia. In an expression of Soekarno, the 1945 Constitution is a Revolutiegrondwet or a constitution of revolution in the sense a constitution with its function to transform radically politics and social-economic system from colonial to national system. ${ }^{11}$ The radical transformation is revolution and the constitution with radical transformation function is a constitution of revolution.

In this context, the effort to adopt some provisions of the 1945 Constitution into the Provisional Constitution of 1950 reflected a spirit to respond the normative tension between the Provisional Constitution of 1950 and the Round Table Conference agreements. Specifically, the adoption of the essential articles of the 1945 Constitution into the Provisional Constitution of 1950 shows that the founding fathers have a consistency with the revolution aspire of Indonesia, so that they have a same response when exercised the agreement of Round Table Conference. It means the essential has purpose to keep the continuity of decolonization as a basic ideas and desire of the 1945 Constitution. Although the 1945 Constitution has been replaced by the Provisional Constitution of 1950, the essentially of the 1945 Constitution still exist as the basic law of the RI.

\footnotetext{
${ }^{11}$ Soekarno stated the Revolutiegrondwet for the first time at a session of the Preparatory Committee for Independence of Indonesia (PPKI) on 18 August 1945. See A.B. Kusuma, Labirnya Undang-Undang Dasar 1945, Badan Penerbit FHUI, Jakarta, 2004, p. 470.
} 


\section{The Agreement of the Amendment}

After the MPR was established based on the general election 1999, agenda of reformation was followed by the amendment of the 1945 Constitution. One of basic argumentation of the amendment of the 1945 Constitution is a speech of Soekarno on 18 August 1945 before the Preparation Committee for Independence of Indonesia (PPKI), which stated that the 1945 Constitution is a Revolutiegrondwet or a constitution of revolution. In that speech, Soekarno said that the 1945 Constitution as a Revolutiegrondwet is a provisional or quickly developed. ${ }^{12}$ It means the Revolutiegrondwet is understood as a process, not a concept. Based on this meaning, the drafters of the amendment of the 1945 Constitution viewed that the 1945 Constitution should be amended because the 1945 Constitution was made in a fast process so that the 1945 Constitution has character as a provisional constitution. ${ }^{13}$

In relation to those meaning, members of the MPR had made the political agreements concerning the amendment of the 1945 Constitution. There are five agreements that are: a. no change in the Preamble of the 1945 Constitution; b. Maintaining the Unitary State of the Republic of Indonesia; c. reinforcement the presidential system; d. the Annotation of the 1945 Constitution which contain normative matters would be entered to articles (body) of the constitution; e. the amendment would be exercised by addendum.

Based on those agreements, the MPR has amended the 1945 Constitution four times during 1999, 2000, 2001 and 2002. Among new provisions of the amendment of the 1945 Constitution are the popular sovereignty principle, the change of system of the government from a hybrid system to a "pure" presidential system, more complete of human rights, the establishment of the DPD, the establishment of Constitutional Court, and the structure of the constitution that only consist of preamble and articles.

The change of system of the government is the most important subject of the amendment of the 1945 Constitution. This is not only the change of structure of the government but also related to the change of principle of people sovereignty. Previously, the 1945 Constitution adhere a hybrid system or semi-presidential that combined between supremacy of the MPR as the parliament and the President as a head

\footnotetext{
${ }^{12}$ A.B. Kusuma, Loc. Cit.

${ }^{13}$ Interview with Sri Soemantri, ex-member of Expert Team of PAH II MPR and Chief of Constitution Commisssion which has authority to consolidate the amendment of the 1945 Constitution. Interview is conducted on 24 June 2010 in Jakarta.
} 
executive. The MPR elect the President and as consequence the President responsible to the MPR. Principally, the MPR exercise the people sovereignty in fully and has the highest authority in the state.

However, the third amendment has changed the hybrid system to be a "pure" presidential system. The president is elected directly by the people. The MPR has no authority to elect the President and, as consequence, the President does not responsible to the MPR anymore. This change has implication to amend the people sovereignty principle. Coherence with the change of structure of the government, the sovereignty should be exercised according to the constitution. It means every state body, which is mentioned in the constitution, should exercise the people sovereignty so those state bodies have equal position among them.

The change of structure of the government, basically, is the reinforcement of the presidential system in the 1945 Constitution as stated in the agreement of member of the MPR. The presidential system is viewed as the system of the government that intended by the founding fathers. Thus, according to the agreement of the MPR, the presidential system is the original system of the government in the 1945 Constitution. However, at the same time, the application of the presidential system has changed the system of the government in the of the 1945 Constitution, which also originally was made by the founding fathers. Therefore, the application of the presidential system is still problematic in the Indonesian constitutional system.

\section{Comparison between Two Agreement}

Several matters that can be compared between the essential of the 1945 Constitution and the agreements of the MPR in the constitutional amendment in 1999. First, the essential of the 1945 Constitution only comprises three articles that cannot be amended although the 1945 Constitution was replaced by the Provisional Constitution of 1950. Even the Preamble of the 1945 Constitution was replaced by the new Preamble and the new constitution applied the parliamentary system - not presidential system as ruled in the 1945 Constitution - those articles cannot be amended. Thus, according to the essential of the 1945 Constitution, the Preamble and system of the government can be amended, while the substance of the 1945 Constitution that cannot be changed is the three articles of the essential of the 1945 Constitution.

In the contrary, the agreement of the MPR on amendment of the 1945 Constitution states that the Preamble and the system of the government cannot be changed. 
Meanwhile, there is no agreement or information that the three articles of the essential cannot be changed. Therefore, the fourth amendment of the 1945 Constitution has changed article 33 by add two new provisions (verses) to the article that is:

(4) The organisation of the national economy shall be conducted on the basis of economic democracy upholding the principles of togetherness, efficiency with justice, continuity, environmental perspective, self-sufficiency, and keeping a balance in the progress and unity of the national economy.

(5) Further provisions relating to the implementation of this article shall be regulated by law.

Although the original provisions of article 33 remained unchanged, but the addition of the two provisions to the original article has changed the article 33 of the 1945 Constitution. Normatively, the principle of familial system (kekeluargaan) in the verse (1) of the article 33 has been added by the new several principles in the verse (4). The addition of new principle can be viewed as an explanation or annotation to the principle of family system. However, whatever of its purpose the addition clearly has changed the article 33 of the 1945 Constitution.

Second, there is a different basic argumentation between the essential of the 1945 Constitution and the agreement on the constitutional amendment of 1999 . Based on its basic argumentation, the essential of the 1945 Constitution clearly has normative character in the sense that the three articles of the essential of the 1945 Constitution was viewed as the persistent norms because of its substance. Furthermore, the essential of the 1945 Constitution was an agreement that enacted by the founding fathers, who has the true understanding of content and meaning of the 1945 Constitution. It means the essential of the 1945 Constitution has a normative argumentation based on the original view of the first drafter of the 1945 Constitution. In this point, a legal consideration became a basic argumentation.

Contrary to the essential of the 1945 Constitution, the agreement of the constitutional amendment in 1999 has a more political background because referred to a political traumatic in the past. For instance, the agreement on the Preamble obviously did not only based on a normative consideration, but also based on a historical experience of the constitutional amendment in the Constitutional Asembly (Konstituante) during 1956-1959. In this time, there was a political conflict on the basic of the state of the Republic of Indonesia between two political groups i.e. Islamist and nationalist. The Islamist aspired to make Islam as the basic of the state, while for the nationalist Pancasila should be the basic of the state of the Republic of 
Indonesia. The conflict between those opposing groups was ended by President Soekarno through a Presidential Decree on 5 July 1959, which decided to return to the 1945 Constitution. By the Presidential Decree on 5 July 1959, Pancasila was reaffirmed as the state philosophy and automatically refuse Islam as the state philosophy, but in the same time, the Presidential Decree confessed the Jakarta Charter dated 22 June 1945, which stated that the obligation for the Muslim to apply the Islamic sharia. In consequence, the Presidential Decree was intended as a compromise that made by President Soekarno to refuse Islam as state philosophy, but accepting the Jakarta Charter that historically has tight relation with the 1945 Constitution. ${ }^{14}$ It is clear that the agreement on the Preamble of the 1945 Constitution was intended to prevent the ideological conflict in Indonesia. It means the agreement is based on more political traumatic than a normative reason.

The same matter can be founded in the agreement to reaffirm the presidential system. The background of this agreement referred to a political experience during parliamentary democracy era in 1950s, which the frequency of fall and rise of cabinet was very high so that caused political instability. It caused Soekarno to decide to reapply the 1945 Constitution, which applied the presidential cabinet as a government system which was believed would reduce political instability because the government cannot be dismissed any time by parliament. The Soekarno's view also became a reason for members of the MPR to decide that the presidential system should be strengthened in the amendment of the 1945 Constitution. However, Soekarno viewed the presidential cabinet in context of a hybrid system with supremacy on the MPR. Meanwhile, the amendment of the 1945 Constitution adopted the presidential system in a pure model as practiced in the USA. Nevertheless, it is clear the reason of reinforcing of the presidential system is more traumatic than normative.

The reinforcing of the unity state of the RI also has a political reason based on a political experience during the RUSI era, which applied a federal state. After the RUSI operated in several months in 1949-1950, the Indonesian leaders refused the federal state because it would create a national disintegration of Indonesia. ${ }^{15}$ The view that the federal state will create a national disintegration point out clearly that the amendment of the 1945 Constitution has more political than normative reason.

\footnotetext{
${ }^{14}$ For further explanation about ideological conflict in the Constitutional Assembly can be read in Adnan Buyung Nasution, Aspirasi Pemerintahan Konstitusional di Indonesia, Grafiti, Jakarta, 1995.

15 "Mosi Integral Natsir," Loc. Cit..
} 
Accordingly, the amendment of the 1945 Constitution enacted in Article 37 (5) that the amendment of the 1945 constitution should not change the unitary state of the RI.

Thirdly, there is a paradigm shift from the essential of the 1945 Constitution to the agreement of the amendment of the 1945 Constitution. The essential of the 1945 Constitution is founded on paradigm of decolonization, while the agreement of the amendment of the 1945 Constitution particularly based on democratization. When the Indonesian leaders, who in general they also were the founding fathers, made an agreement of the essential of the 1945 Constitution, they understood what for the constitution was made. The purpose was decolonization or to liberate the state from colonialism, in particular from the Dutch colonialism in politics as well as social and economy.

Contrary to the essential articles above, the agreement of the amendment of the 1945 Constitution has shifted the paradigm of decolonization to democratization. The amendment of the 1945 Constitution has background on desire of democratization. The dictatorship practice during the New Order regime gave an historical experience to restrict the power of government, especially power of the President. Members of the MPR viewed that the main cause of the New Order dictatorship is notions and norms within the 1945 Constitution that gives predominance to the President. Thus, the solution is the amendment of the 1945 Constitution in order to be more democratic.

Based on democratization desire, the amendment of the 1945 Constitution has no agenda to maintain decolonization specifically. The agreement on the amendment did not cover agenda to reaffirm decolonization. The agreement just reaffirmed status of the Preamble, the unitary state, the presidential system, the annotation of the 1945 Constitution and a model for the amendment. Actually, reaffirmation of the Preamble reflected decolonization agenda because philosophically the Preamble contains some decolonization notions. Unfortunately, it did not state explicitly agenda for decolonization. The reaffirmation of the Preamble was mainly required to prevent the Preamble from some political interest that want to amend the Preamble.

Because there is no an explicit agenda to decolonization, in practice the amendment has been driven more by democratization than decolonization. The problem is that democratization has been viewed as a process toward a liberal democracy, which required a support from a suitable economic system. The suitable 
economy system for a liberal democracy is a market economy system. ${ }^{16}$ Conceptually, the market economy system has no orientation to build a national economic system. Principally, there is no restriction in the market. Even each state should open its border to give opportunity for market operation. Thus, the market economy system has purpose to build a global economy, not a national economy system. ${ }^{17}$

In general, there is a different view on the matter that cannot be changed in the 1945 Constitution. At the early independence, the Indonesian leaders viewed that the essential matter of the 1945 Constitution are the article 27, 29, and 33. Those articles cannot be amended though the 1945 Constitution replaced by the new constitution - in this case by the Provisional Constitution of 1950. Meanwhile, after five decades the Indonesian leaders view that the unchanged matter of the 1945 Constitution are the Preamble, the unitary state, and the presidential system.

At the one side, the difference shows an inconsistency among the Indonesian leader in the different time in looking at the amendment of the 1945 Constitution. However, at the other side, the difference informs a paradigm shift among the Indonesian people in looking at the amendment of the 1945 Constitution. At the early independence, the Indonesian people looked upon the amendment of the 1945 Constitution in regard with decolonization desire. However, at the early $21^{\text {st }}$ century the Indonesian people have a look at the amendment of the 1945 Constitution for dealing with democratization demand. It means that the original intents of the 1945 Constitution do not become a main reference anymore for the member of the MPR in 1999.

\section{Conclusion}

From description above, there are several conclusions that could be comparison between the essential of the 1945 Constitution on 1950 and the agreement of the 1945 Constitution on 1999. First, there is a same view that the essential and the agreement have purpose to maintain the 1945 Constitution in order that the essential or the

\footnotetext{
${ }^{16}$ The goal of democratization of Indonesia since 1998 is to create a political system that suitable with the free market system. See Tim Weiner, “Unrest In Indonesia: The Opposition; U.S. Has Spent \$26 Million Since '95 on Suharto Opponents," in The New York Times, 20 Mei 1998 (accessed on 25 August 2010).

17 This view was reflected in opinion of Sarbini Sumawinata, who was one of the architect of economic development of the New Order. He refused a national economic system and suggested a rational economic system based on free market rules. See Sarbini Sumawinata, "Garis-garis Besar Pembangunan Ekonomi Indonesia," in Hadi Soesastro, et al. (eds.), Pemikiran dan Permasalahan Ekonomi di Indonesia dalam Setengah Abad Terakhir (Buku I 1945-1959, Membangun Ekonomi Indonesia, Yogyakarta: Kanisius, 2005. (eds.), pp. 131-2. See also David Harvey, Neoliberalisme dan Restorasi Kelas Kapitalis, Resist Book, Yogyakarta, 2009, pp. 107-110.
} 
persistent matter of the 1945 Constitution cannot be changed when the 1945 Constitution will be amended. However, it does not mean that the essential and the agreement have the same issue. The essential consist of three articles that is article 27, 29, and 33 of the 1945 Constitution, while the agreement has five topics that are maintaining the Preamble, reinforcing the unitary state, reaffirmation the presidential system, the adoption of the annotation of the constitution, and the addendum is the way of amendment. The differences between the essential and the agreement reflect a paradigm shift from decolonization to democratization. The paradigm shift can be occurred due to some causal factors such as politics, national as well as global, economy, social, and cultural, which surrounded when the constitutional amendment was happened. The paradigm shift shows that the constitutional amendment in 1999 did not refer to the original intents of the 1945 Constitution, which was intended by the founding father. Second, consequently, the amendment of the 1945 Constitution relatively has changed the basic intention of the 1945 Constitution from decolonization to democratization.

\section{References}

Anderson, Benedict, Komunitas-Komunitas Imajiner: Renungan tentang Asal-Usul dan Penyebaran Nasionalisme, Pustaka Pelajar/Insist, Yogyakarta, 1999.

Anshari, Endang Syaifuddin, Piagam Jakarta 22 Juni 1945 dan Sejarah Konsensus Nasional antara Nasionalis Islami dan Nasionalis Sekular tentang Dasar Negara Republik Indonesia 1945-1959, Gema Insani Press, Jakarta, 1997.

Azhari, Aidul Fitriciada, Tafsir Konstitusi Pergulatan Mewujudkan Demokrasi di Indonesia, Jagad Abjad, Surakarta, 2010.

Harvey, David, Neoliberalisme dan Restorasi Kelas Kapitalis, Resist Book, Yogyakarta, 2009.

Kahin, George McTurnan, Nationalism and Revolution in Indonesia, Cornell University Press, Ithaca/London, 1952.

Kusuma, A.B., Lahirnya Undang-Undang Dasar 1945, Badan Penerbit FHUI, Jakarta, 2004.

Loomba, Ania, Kolonialisme/Pascakolonialisme, Bentang Budaya, Yogyakarta, 2003.

MPR, Badan Pekerja, Perubahan Pertama dan Perubahan Kedua UUD 1945: Bahan Penjelasan BP-MPR dalam Rangka Memasyarakatkan Hasil Sidang Umum MPR 1999 dan Sidang Tahunan MPR 1999, Sekretariat MPR, Jakarta, 2000.

Nasution, Adnan Buyung, Aspirasi Pemerintahan Konstitusional di Indonesia, Grafiti, Jakarta, 1995. 
Paton, George Whitecross, A Textbook of Jurisprudence, Clarendon Press, Oxford, 1951.

Stone, Julius, Human Law and Human Justice, Maitland Publications, Sydney, 1965.

Sumawinata, Sarbini, "Garis-garis Besar Pembangunan Ekonomi Indonesia," in Hadi Soesastro, et al. (eds.), Pemikiran dan Permasalahan Ekonomi di Indonesia dalam Setengah Abad Terakhir (Buku I 1945-1959, Membangun Ekonomi Indonesia, Kanisius, Yogyakarta, 2005.

Wignjosoebroto, Soetandyo, Dari Hukum Kolonial Ke Hukum Nasional - Dinamika SosialPolitik dalam Perkembangan Hukum di Indonesia, RajaGrafindo Persada, Jakarta, 1994.

Yamin, Muhammad, Naskah Persiapan Undang-Undang Dasar 1945, Jakarta, 1960.

The 1945 Constitution and Its Amendment

The Constitution of Republic of the United State of Indonesia (LNRI 1950, No. 2).

The Provisional Constitution of the Republic of Indonesia (LNRI 1950, No 56)

Presidential Decree No. 150 / 1959 about Decree of the President of the Republic of Indonesia/The Higher Commander of Army Forces about Return to the 1945 Constitution (LNRI No. 75, 1959).

“Classical Liberalism” in http:/ / en.wikipedia.org/wiki/Classical_liberalism (accessed on 7 Oktober 2009).

“Mosi Integral Natsir", http:/ /id.wikipedia.org/wiki/Mosi_Integral_Natsir (accessed on 20 July 2010).

"Property" in http:/ / en.wikipedia.org/ wiki/ Property (accessed on 7 October 2009).

"Tierra y Libertad: The Social Function Doctrine and Land Reform In Latin America" in http://www.law.ufl.edu/cgr/conference/06confmaterials/8_Panel/ 8_TomAnkersen.powerpoint.pdf (accessed on 7 October 2009).

Weiner, Tim, “Unrest In Indonesia: The Opposition; U.S. Has Spent \$26 Million Since '95 on Suharto Opponents," in The New York Times, 20 Mei 1998 (accessed on 25 August 2010. 